\title{
Influence of dyeing and printing industrial effluent on physicochemical Characteristics of water - Case study on the printing cluster of Bagru, Jaipur (Rajas than), India.
}

\author{
${ }^{1}$ Neetu Sharma,${ }^{2}$ Sunil k. Sharma, ${ }^{3}$ Abhishek Gehlot \\ ${ }^{1}$ Department of Chemistry and Environment Engineering. Global Institute of Technology, India \\ ${ }^{2}$ Department of Chemistry and Environment Engineering. Jagannath University, India \\ ${ }^{3}$ Department of Chemistry, Jaipur National University, India
}

\begin{abstract}
In Rajasthan state printing and dyeing units represent an important economic sector.bagru in Jaipur district has got many printing and dyeing industry, in this industry Natural and vegetable dyes are mainly used for printing but some enterprises make use of synthetic dyes and mordants. So, the disposal of waste water effluents is a big problem in such industries. If the untreated water, directly disposed into open drains, the particulate may become the part of ground water due to seeping or it may directly used for crop cultivation. Dye house effluents are not only responsible for soil contamination but also responsible for water contamination. The present study is based on the determination of various physio chemical parameters of water due to direct disposal of untreated water in water sources in rainy season i.e. in the month of July, August and September 2013 and results are compared to textile effluent standards prescribed by Rajasthan state pollution control board.
\end{abstract}

Keywords: Textile industry, Textile effluent, Discharge limit, physio chemical properties, Water Pollution

\section{Introduction}

The textile industries are large industrial consumers of waters as well as producers of waste water. The effluent discharged by this industry leads to serious pollution of groundwater and soils and ultimately affects the livelihood of the poor. The Jaipur is the capital of Rajas than state and have a unique category in tourism and corporate world for tourism and Business market and Resources. The Jaipur, mainly known as Pink City around the world for its Traditional Art \& Craft, Handicraft, History, Tradition and Historical themes. Bagru is known place for Natural Dyes, Indigo Dyes and Block Printing around the world. Bagru has a unique place in Textile Industry Resources. Bagru is situated in geographical $26^{\circ} 49^{\prime}$ 0North, $75^{\circ} 33^{\prime} 0$ East of Jaipur (Pink City) at National Highway No.8 (Delhi - Jaipur - Mumbai GVK Express way) and 30 K.M. far from Jaipur. The history of Bagru printing is about 350 years old. The main community of Bagru is Chippa and Raiger. These communities are migrated from jaipur and settled in the Bagru because due to presence of Sanjaria river, there is availability of water and chikkni mitti, required for dyeing process, even though the river dried up 20years ago, many printing families resides in the area. This town is famous for Dabu printing. In all there are 250printing units. The coloured effluents of various cluster units (dyeing and printing units) of Bagru have got much attention to their dual toxicity. Also the effluent from these units and industries were discharged in open land, agriculture land, thus causing an adverse effect on flora, fauna and general health of residents residing in the communities within around the sides, and villages. The study is based on the analysis of physio chemical properties of water in Bagru textile area, which can help in identification of environmental impacts due to dumping of textile waste water in water bodies and further use of this waste water for irrigation samples were collected in the month of June, July and August for comparative study of the leaching concentration of various dye pollutants in water bodies.

\subsection{Collection of sample}

\section{Material And Method}

Different polluted water samples were collected from various locations viz.hand washings of dye industry in polythene as shown in figure-1., Immediate to dumping site and main drainage and then brought to laboratories for further analysis. 


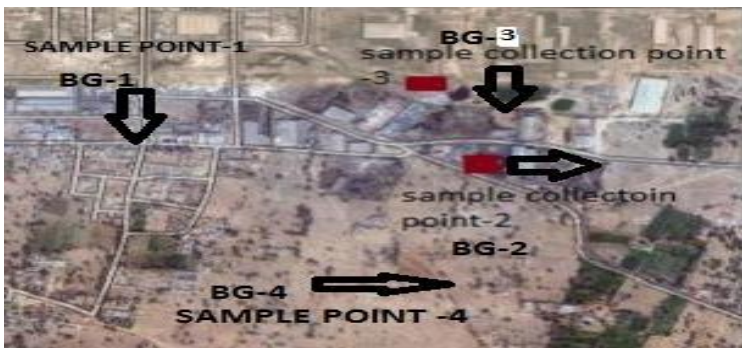

Figure -1 Satellite view of Study area and sample collection point (BG-1= dye wash water sample, BG-2= dyeing effluent, BG-3= water sample near dyeing unit, BG-4= water sample away from area)

\subsection{Analysis of sample}

The collected water samples were analysed for the various physico- chemical parameters like $\mathrm{pH}$, temperature, electrical conductivity, total dissolve solid, salinity, dissolve oxygen, chemical oxygen demand and chloride content. The $\mathrm{pH}$, electrical conductivity, total dissolved solids, total suspended solids parameters were analysed by using up based water analysis kit and the other parameters viz. dissolved oxygen, chemical oxygen demand and chloride content were analysed by adopting standard procedures viz volumetric analysis. all the experiment analysis were conducted at the research facility at environment engineering laboratory at Jagannath University, Global Institute of Technology and National test house situated in Jaipur Physicochemical Parameters of water were analyzed by standard methods (APHA, 1998).

\subsubsection{Apparatus}

Deluxe $\mathrm{pH}$ meter $-101,1302283$, manufactured by EI was used for $\mathrm{pH}$ measurement, to determine the electro-conductivity of waste water sample, a measured volume of sample in the beaker was prepared and Deluxe conductivity meter 601, manufactured by EI was used, Digital TDS meter -651 manufactured by EI was used to determine the TDS of the waste water sample, The BOD tests were carried out using standard procedure using a five-day BOD test whileChemical Oxygen Demand (COD) was determined by the Dichromate Reflux Method.

\section{Experimental Result Analysis}

\section{Physio chemical analysis of samples:}

The effluents differed substantially from one another with respect to chemical characteristics. The $\mathrm{pH}$ of the effluents ranged from 7.1-8.6, electrical conductivity (EC) from 1.39-5.0 ms and temperature between 25.0-31. $0^{\circ} \mathrm{C}$. Total dissolved solids were between $80-318 \mathrm{mg} / \mathrm{L}$ as shown in table 1-3.

Table-1- Analysis of water samples collected in the month of June 2013

\begin{tabular}{|c|c|c|c|c|c|}
\hline \multirow{2}{*}{$\begin{array}{c}\text { Water } \\
\text { sample }\end{array}$} & \multicolumn{5}{|c|}{ Physico- chemical parameters } \\
\cline { 2 - 6 } & $\mathbf{p H}$ & $\mathbf{E C}(\mathbf{m s})$ & $\mathbf{T D S}(\mathbf{m g} / \mathbf{l})$ & $\mathbf{C O D}(\mathbf{m g} / \mathbf{l})$ & $\mathbf{B O D}(\mathbf{m g} / \mathbf{l})$ \\
\hline BG1 & 8.1 & 1.42 & 1171 & 896 & 410 \\
\hline BG2 & 6.7 & 3.36 & 2612 & 1997 & 430 \\
\hline BG3 & 7.3 & 4.22 & 1288 & 560 & 210 \\
\hline BG4 & 6.9 & 4.16 & 279 & 35 & 50 \\
\hline
\end{tabular}

Here: $\mathbf{E C}=$ Electrical conductivity $; \mathbf{T D S}=$ Total Dissolved Solids; $\mathbf{B O D}=$ Biological oxygen demand COD=Chemical Oxygen Demand

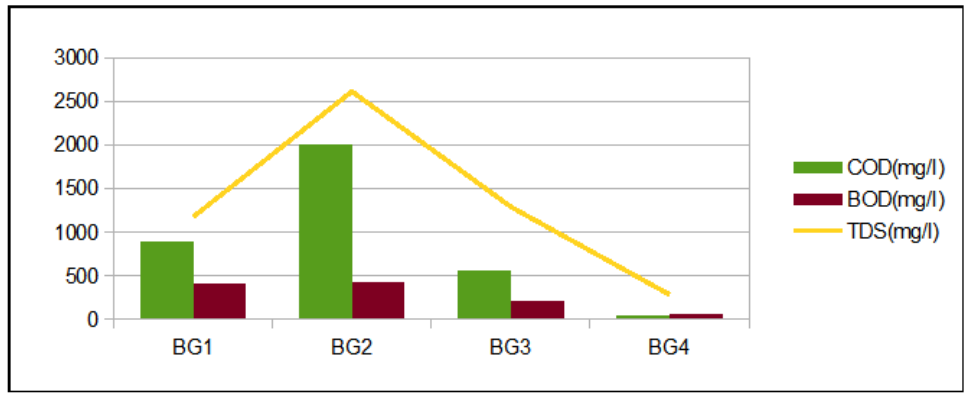

Figure -2 Analysis of water samples collected in the month of June 2013 
Influence of dyeing and printing industrial effluent on physicochemical Characteristics of water-

Table-2- Analysis of water samples collected in the month of July 2013

\begin{tabular}{|c|c|c|c|c|c|}
\hline \multirow{2}{*}{$\begin{array}{c}\text { Water } \\
\text { sample }\end{array}$} & \multicolumn{5}{|c|}{ Physico- chemical parameters } \\
\cline { 2 - 6 } & $\mathbf{p H}$ & EC(ms) & TDS(mg/l) & COD(mg/l) & BOD(mg/l) \\
\hline BG1 & 7.6 & 2.35 & 1260 & 916 & 495 \\
\hline BG2 & 6.9 & 4.42 & 2542 & 2126 & 435 \\
\hline BG3 & 7.1 & 4.62 & 1468 & 490 & 170 \\
\hline BG4 & 7.0 & 4.76 & 240 & 40 & 30 \\
\hline
\end{tabular}

Here: $\mathbf{E C}=$ Electrical conductivity; $\mathbf{T D S}=$ Total Dissolved Solids; $\mathbf{B O D}=$ Biological oxygen demand, COD $=$ Chemical Oxygen Demand

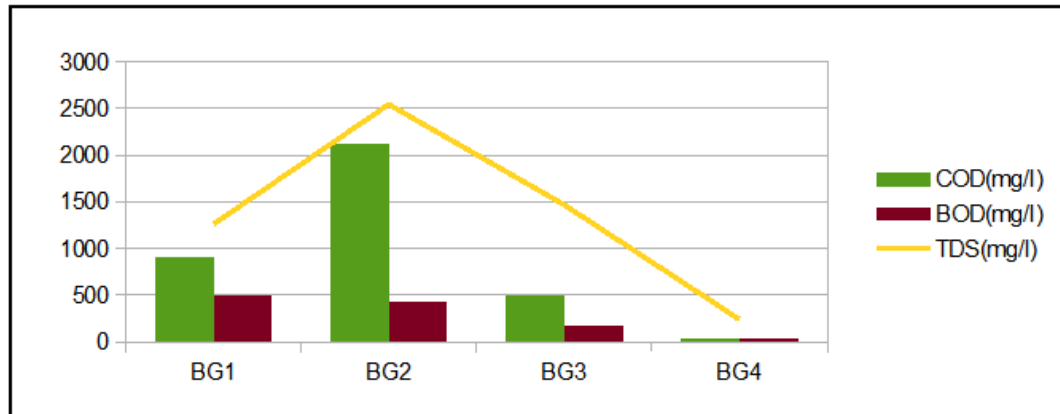

Figure -3 Analysis of water samples collected in the month of July 2013

Table-3- Analysis of water samples collected in the month of Aug 2013

\begin{tabular}{|c|c|c|c|c|c|}
\hline \multirow{2}{*}{$\begin{array}{c}\text { Water } \\
\text { sample }\end{array}$} & \multicolumn{5}{|c|}{ Physico- chemical parameters } \\
\cline { 2 - 6 } & $\mathbf{p H}$ & EC(ms) & TDS(mg/l) & COD(mg/l) & BOD(mg/l) \\
\hline BG1 & 7.2 & 2.46 & 1265 & 890 & 455 \\
\hline BG2 & 7.3 & 4.64 & 2540 & 2217 & 483 \\
\hline BG3 & 7.1 & 4.68 & 1350 & 475 & 21 \\
\hline BG4 & 7.0 & 4.76 & 223 & 30 & 21 \\
\hline
\end{tabular}

Here: $\mathbf{E C}=$ Electrical conductivity; $\mathbf{T D S}=$ Total Dissolved Solids; $\mathbf{B O D}=$ Biological oxygen demand. COD=Chemical Oxygen Demand

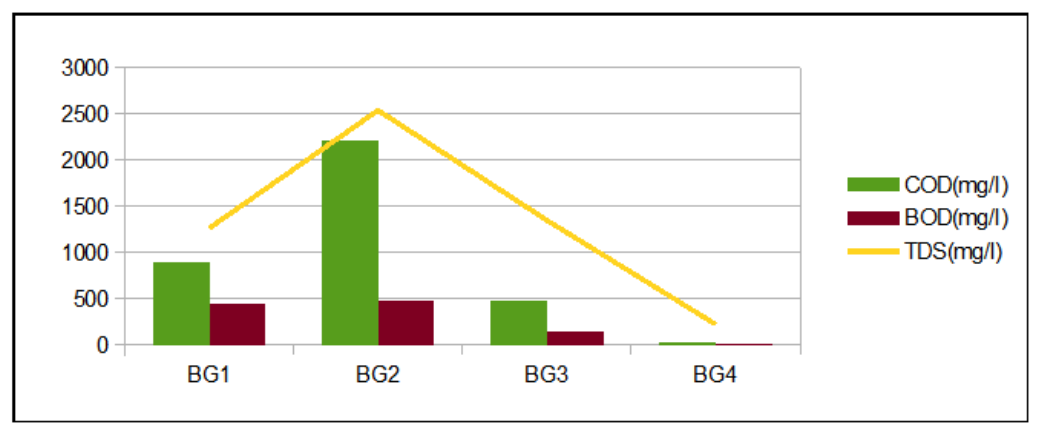

Figure -4 Analysis of water samples collected in the month of Aug 2013

pH:

\section{Discussion}

$\mathrm{pH}$ between 6.9 to 8.6 of study area which is not very harmful for aquatic life.

Total dissolved solids:

TDS ranged between July to august 2013 is $223-2600 \mathrm{mg} / \mathrm{l}$ which is highest for dyeing effluent in the month of July and minimum (223 mg/l) for the sample BG-4 taken away form study area 


\section{Chemical oxygen demand:}

COD ranged between 30-2217 mg/l during July to august 2013 and highest for dyeing effluent and for other sample are ranged between $475-560 \mathrm{mg} / \mathrm{l}$ and minimum for BG-4 is $30-40 \mathrm{mg} / \mathrm{l}$.

\section{Biological oxygen demand:}

BOD concentration ranged between 21-495 mg/l for all sample (BG-1,BG-2,BG-3,BG-4) except BG -4 all other samples having higher concentration which is higher than the prescribed limit by Pollution- Control Board, Rajasthan (India), only BG-4 sample with in the limit of drinking purpose.

\section{Electrical Conductivity:}

Electrical Conductivity measures the amount of dissolved ionic impurities in water. Greater the conductivity greater will be the ionic impurities in water ranged between $1.42-4.76 \mathrm{~ms}$ during period which is more then permissible limit.

\section{Conclusion}

Water Sample Quality in bagru region has been analysed in the present work. water samples showed great variation in the physico-chemical properties and exceeds the prescribed permissible limit of TDS, COD, BOD and EC. The physico-chemical characterization of the collected textile effluent sample from Bagru region showed a high load of pollution indicators. The results obtained this study are expected to contribute to control the textile industry, Waste-water pollution and to protect aquatic environment in study area as well as health of residing people.

\section{Recommendation And Future Scope}

- $\quad$ Encourage cultivation of dye-bearing plants on local wastelands.

- $\quad$ Establishment of Common effluent treatment plant (CETP) by State Goverment.

- $\quad$ Synthetic dyes replaced by natural dyes and Contact yer communities who used to use natural dyes.

\section{Acknowledgment}

Special thanks to the Honorable Chancellor Mr. Sandeep Bakshi, Jaipur National University as well as the for their motivation and financial support and Ms. Akanksha Gaur, Assistant Professor in Computer Engineering, Jaipur National University for her assistance.

\section{References}

[1]. Agarwal R, Agarwal SK (1990) Physico-chemical characteristics of saree printing effluent, its effect on seed germination and seedling growth of Cymopsis tetragonoloba. Acta Ecol Sin, 12:112-118.

[2]. APHA (1992) Standard methods for the examination of water and waste water American Public Health Association (18 ${ }^{\text {th }}$ Ed) Academic Press, Washington DC, 214- 218.

[3]. Indian Standards Institute (ISI), Tolerance Limit for Industrial Effluents Discharged on Land for Irrigation Purposes, IS: 3307 (1977).

[4]. Narwal R.P., A.P. Gupta, A. Singh and S.P.S. Karwasra, Composition of Some City Waste Waters and Their Effect on Soil Characteristics, Ann. Biol., 9, 239. 245 (1993)

[5]. Patel H. and Pandey S., Physico-chemical characterization of textile chemical sludge generated from various CETPS in India, J. Environ. Res. Develop., 2(3), 329-339, (2008).

[6]. Standard Methods for the Examination of Water and Wastewater, 22nd Edn., APHA (American Public Health Association), 45- 60, (2012).

[7]. Standard Methods for the Examination of Water and Waste water, 21st ed, APHA (American Public Health Association), (2011).

[8]. Sharma, D.K., J.P. Jangir, C.P.S. Chandel and C.M. Gupta, Studies in Quality of Water in and around Jaipur. Part I, J. Indian Water Works Association, 257.260 (1988).

[9]. Sharma Alka, Sharma D.K., J.P. Jangir and C.M. Gupta, Studies of Trace Elements in Water in and Around Jaipur, Indian Journal of Environ. Prot., 9(4), 294.296 (1989).

[10]. WHO. Guidelines for technologies for water supply systems in small communities (World Health Organization, CEHA) (2006).

[11]. Yusuf, R.O. and Sonibare, J.A. (2004) Characterisation of textile industries effluents in Kaduna, Nigeria and Olayinka, Studies on industrial pollution in Nigeria. The effects of textile effluents on the quality of ground water in some parts of Lagos, Nigerian Journal of Health and Biomedical Sciences vol.3 pp 44-50. 